\title{
„DROGA SERCA” W DOŚWIADCZENIU I REFLEKSJI ŚW. AUGUSTYNA
}

\author{
„[Panie], stworzyłeś nas jako skierowanych ku To- \\ bie. I niespokojne jest serce nasze, dopóki w Tobie nie \\ spocznie". ${ }^{1}$
}

To zdanie św. Augustyna, stanowi najprawdopodobniej jedną z najbardziej znanych wczesnochrześcijańskich myśli, która na dodatek nie utraciła nic ze swojej aktualności. Znamienne, że została ona przywołana jako pierwszy cytat patrystyczny w Katechizmie Kościoła Katolickiego (nr 30) na zakończenie rozdziału o pragnieniu Boga. ${ }^{2}$ Istotnie, termin ,serce”, z całą jego pojemnością znaczeniową, wskazywał od wieków tę intymną i osobistą rzeczywistość, w której człowiek spotyka się ze sobą, z innymi i z samym Bogiem.

Antoine Guillaumont uważał, że żadne pojęcia antropologiczne nie są tak semantycznie różnorodne, jak „dusza”, „duch”, „serce”. 3 Nie ograniczają się bowiem do ram przestrzenno-czasowych, ale wnikają w sferę transcendencji. ${ }^{4}$ Choć serce jest symbolem uniwersalnym,

1 A u g u s t i n u s, Confessionum Libri XIII I, 1.1: „Fecisti nos ad te, [Domine] et inquietum est cor nostrum, donec requiescat in te" (wszystkie cytaty łacińskie w serii: Nuova Biblioteca Agostiniana, Città Nuova, Roma; dostępne także na www.augustinus.it; tłumaczenie polskie w: Ś w i ęt y A ugustyn, Wyznania, tłum. W. K u bi a k, I. W. Pax, Warszawa 1987, s. 7; dalej: Conf.).

2 KKK 27: „Pragnienie Boga jest wpisane w serce człowieka, ponieważ został on stworzony przez Boga i dla Boga. Bóg nie przestaje przyciągać człowieka do siebie i tylko w Bogu człowiek znajdzie prawdę i szczęście, których nieustannie szuka".

3 A. G u illa u mo n t, Znaczenie słowa ,, serce” $w$ starożytności, tłum. S. W i r p s z a n k a, w: Uźródel monastycyzmu chrześcijańskiego, t. 2, Źródła monastyczne 38, Wydawnictwo Benedyktynów, Kraków 2006, s. 13.

4 Por. M. A. W a g n e r, A Reflection on the Use of ,Heart” in Select Prayer Texts in Early Christianity, w: H. A. L u c k m a n, L. K u $1 \mathrm{z} \mathrm{e} \mathrm{r,} \mathrm{Purity} \mathrm{of} \mathrm{Heart} \mathrm{in}$ 
to jednak w różnych epokach i kulturach miało specyficzne odcienie znaczeniowe. Na myśl wczesnochrześcijańską oddziaływały zasadniczo dwa czynniki: Pismo Święte i świat kultury grecko-rzymskiej. W księgach zarówno Starego, jak Nowego Testamentu, a także w dziełach epoki poapostolskiej, mamy do czynienia z metaforycznym rozumieniem ,serca” jako ośrodka życia wewnętrznego (uczuciowego, moralnego, intelektualnego, religijnego). W III w., zwłaszcza w środowisku aleksandryjskim, dominujący wpływ hellenizmu i filozofii platońskiej doprowadził do zawężonej, choć bardziej jednolitej, interpretacji, polegającej na utożsamianiu go z, ,intelektem" (nous, animus). Natomiast Ojcowie Łacińscy pozostawali na ogół wierni biblijnej wieloznaczności i terminologii, czego przykładem jest Wulgata. ${ }^{5}$

Celem niniejszego studium jest ukazanie różnorodności znaczeniowej oraz duchowych implikacji łacińskiego terminu cor w twórczości św. Augustyna (†430). Ze względu na częstotliwość występowania tego pojęcia, analiza zostanie oparta w zasadniczej mierze na jego komentarzach do psalmów, Ewangelii św. Jana oraz Pierwszego Listu św. Jana, choć nie zabraknie odniesień także do innych dzieł. Odwołania do Wyznań natomiast pomogą unaocznić wpływ osobistego doświadczenia sławnego biskupa Hippony na specyfikę jego rozważań. Istotnie, przez wiele lat poszukiwał szczęścia i sensu życia, przemierzając szlaki wiedzy, kariery, przyjemności. Wewnętrzna tułaczka naznaczona różnymi fascynacjami filozoficznymi i religijnymi doprowadziła go nawet na skraj zwątpienia. Gdy miał 32 lata, został olśniony blaskiem prawdy Chrystusowej i dotknięty uzdrawiającą mocą Bożej łaski. ${ }^{6}$ Wtedy wyznał, że pokój serca można znaleźć jedynie w Bogu, wytyczając w ten sposób drogę duchowego wzrostu dla kolejnych pokoleń.

Early Ascetic and Monastic Literature. Essays in Honor of Juana Raasch, O.S.B, The Liturgical Press, Collegeville, Minesota, 1999, s. 131-139.

5 Por. A. G u i 11 a u m o n t, Znaczenie słowa ,serce”, s. 65-66.

6 Por. W. E b or o w i c z, Proces nawrócenia św. Augustyna, Vox Patrum 8 (1988) t. 14, s. 67-79. 


\section{Wieloznaczność semantyczna terminu cor}

Święty Augustyn przedstawiany jest często na obrazach z sercem przeszytym strzałą i otoczonym przez ogniste płomienie. Te symbole wszechogarniającej miłości są ikonograficznym wyrazem jego niezwykle osobistych słów: „Przeszyłeś moje serce, jak strzałą, Twoją nadziemską miłością" $\mathrm{i}$ „Swoim słowem ugodziłeś moje serce i pokochałem Cię". ${ }^{8}$ W pismach Augustyna termin cor występuje ponad 8 tys. razy, ${ }^{9}$ najczęściej podczas cytowania i komentowania Biblii oraz w opisach osobistych przeżyć.

Dla Augustyna ,serce" stanowi centrum osoby i jest synonimem człowieka wewnętrznego (homo interior)..$^{10} \mathrm{~W}$ nim mieści się życie afektywne, intelektualne, moralne i religijne. Ono wyraża duchowy dynamizm i działanie typowo ludzkie. Jest siłą wewnętrzną, która pozwala człowiekowi w sposób wolny skierować się w stronę dobra lub zła oraz przyjmować odpowiedzialność za podjęte decyzje i dokonane czyny. Ono wreszcie jest siedliskiem mądrości i uprzywilejowanym miejscem objawiania się Boga, nawet jeśli nie zostanie On w pełni rozpoznany.

W początkowej fazie twórczości, to znaczy tuż po nawróceniu, Augustyn był przesiąknięty mentalnością platońską, co znajdowało wyraz w jego traktatach filozoficznych. Na tym etapie starał się unikać wieloznacznego terminu cor, stosując zamiast niego zgodne z platońską antropologią i bardziej precyzyjne pojęcia, takie jak mens, intelligentia czy animus. ${ }^{11}$ Ta filozoficzna tendencja dawała o sobie

7 Conf. IX, 2.3: „Sagittaveras tu cor nostrum caritate tua”; tłum. pol. W. Ku bi a k, s. 190.

8 Tamże X, 6.8: „Percussisti cor meum verbo tuo, et amavi te”; thum. pol. tamże, s. 223.

9 Por. G. M a d e c, Cor, w: C. M a y e r, Augustinus-Lexicon, Basel 1996-2002, t. 2, s. 1-6.

10 Por. A. S o 1 ig n a c, Homme intérieur: Augustin, w: Dictionnaire de spiritualité, ascétique et mystique, doctrine et histoire, t. VII/1, Paris 1969, s. 655-658; J. C a m p o s, El ,homo interior”, La Ciudad de Dios 187/1974, s. 5-28.

11 Por. A ug u s t i n u s, De Quantitate Animae Liber Unus 14, 23; 33, 75. 
znać także i później. W komentarzach do psalmów Augustyn czasem utożsamia ,serce" z władzą intelektualną. ${ }^{12}$ Myśleć to rozmawiać ze sobą w sercu. ${ }^{13} \mathrm{~W}$ nim mieści się też władza, która pozwala osądzić co jest dobre, a co złe. ${ }^{14}$ Augustyn zauważa, że nawet zły człowiek potrafi właściwie osądzić, jeśli na tym nic nie traci. ${ }^{15}$ Zakłada to istnienie jakiejś formy prawa naturalnego, zwanego ,złotą regułą”: „Nie czyń drugiemu, czego nie chcesz, aby inni tobie czynili”. ${ }^{16}$

Augustyn, w przeciwieństwie do autorów chrześcijańskich stosujących się całkowicie do wymagań platonizmu, nie uciekał od wiązania serca z uczuciami. Co więcej, uznawał, że są one jedną $\mathrm{z}$ bardziej istotnych sił wpływających na dynamikę serca. Jego zdaniem, to właśnie one określają jego status, to znaczy jego przynależność do Babilonu, czyli królestwa pychy, lub do Jerozolimy, tj. stolicy Boga. ${ }^{17}$ Biskup Hippony podkreślał, że tylko miłość może zintegrować serce, ${ }^{18}$ a uczucia są jego „nogami”, ${ }^{19}$ dzięki którym przechodzi się od umiłowania świata (amor saeculi) do miłości Boga (amor Dei), od pożądliwości (cupiditas) do miłości (caritas). „Jeden i ten sam człowiek, ciałem znajduje się w jednym miejscu i miłując Boga podchodzi do Boga, a umiłowawszy nieprawość, odchodzi od Boga (...). Na tej drodze naszymi nogami są uczucia. Zależnie od

12 Por. te n ż e, Enarrationes in Psalmos 7, 9; 57, 1 (dalej: En. Ps.). W niektórych rozważaniach Augustyna cor wydaje się pojęciem szerszym niż conscientia; por. E. d e la P e z a, El significado de „cor” en san Agustín, Paris 1962, s. 87; I. B o c h e t, Cor, w: A. D. F it z g e r a ld, Agostino: dizionario enciclopedico, Città Nuova, Roma 2007, s. 524.

13 Por. A u g u s t i n u s, De Trinitate Libri Quindecim XV, 10.19.

14 Por. t e n ż e, In Evangelium Ioannis Tractatus Centum Viginti Quatuor 18, 10 (dalej: Ev. Io. Tr.). Szerzej: M. Te r k a, O sumieniu. Przyczynki do synejdezjologii św. Augustyna, w: R. C e g l a r e k, M. S z t a b a, Być człowiekiem sumienia. Interdyscyplinarny namyst nad fenomenem sumienia, Częstochowa 2015, s. 159-194.

15 Por. En. Ps. 57, 1.

16 Por. Ev. Io. Tr. 49, 12.

17 Por. En. Ps. 136, 2.

18 Por. Ev. Io. Tr. 39, 5.

19 Por. En. Ps. 64, 2. 
tego, jakie uczucia ktoś żywi, jaką miłością się kieruje, odchodzi albo przychodzi do Boga". ${ }^{20}$

Pojmowanie „serca” jako synonimu człowieka wewnętrznego (homo interior) znalazło swój wyraz w przypisywaniu mu posiadania różnych niewidzialnych zmysłów, na podobieństwo tych cielesnych: oczu, uszu, smaku, powonienia, dotyku, a także rąk, ust, języka, żołądka itp. ${ }^{21}$ „Smak serca" pozwala rozkoszować się prawdą. Jeśli natomiast jest on skażony, to słowo Boże ma gorzki smak. ${ }^{22}$ „Oko serca” pozwala dostrzec prawdziwe intencje, sprawiedliwość, uczciwość, łagodność, wierność, miłość itp. ${ }^{23}$ Kiedy jest uszkodzone, a nawet całkowicie ślepe, człowiek błądzi. ${ }^{24} \mathrm{Z}$ sercem może też nie zgadzać się język z powodu obawy przed czymś albo z chęci oszukania. Z natury wprawdzie mowa nie jest zdolna wyrazić rzeczywistości wewnętrznej sercu, ale człowiek powinien zawsze dążyć do prawdy i być jej świadkiem. ${ }^{25}$ Mówiąc o „zmysłach serca”, nie należy jednak zapominać, że w antropologii Augustyna podstawową opozycję stanowi dusza (serce) i ciało. Podkreślał on, że można być blisko Chrystusa ciałem, a jednocześnie bardzo daleko sercem, ${ }^{26}$ jak np. Judasz ${ }^{27}$ czy żołnierze,

20 En. Ps. 94, 2: „Unus ergo idemque homo corpore stans uno loco, et amando Deum accedit ad Deum, et amando iniquitatem recedit a Deo (...). Pedes enim nostri in hoc itinere, affectus nostri sunt. Prout quisque affectum habuerit, prout quisque amorem habuerit, ita accedit vel recedit a Deo" ; tłumaczenie polskie w: A u g u s t y n, Objaśnienia Psalmów, tłum. J. S u 1 o w s k i, PSP 40, Warszawa 1986, s. 255.

21 Por. En. Ps. 125, 8; Ev. Io. Tr. 18, 10; 32, 4.

22 Por. A u g u stinu s, In Epistolam Ioannis ad Parthos Tractatus Decem, Prologus (dalej: Ep. Io. Tr.).

23 Por. En. Ps. 33 (2), 15; Ev. Io. Tr. 18, 10.

24 Por. Ev. Io. Tr. 2, 16; 14, 12; 18, 11; 35, 9; En. Ps. 57, 22. Szerzej, por. G. G i 1 le t t e, Purity of Heart in St. Augustine, w: H. A. L u c k m a n, L. K u l z e r, Purity of Heart in Early Ascetic and Monastic Literature. Essays in Honor of Juana Raasch, O.S.B, s. 176-178.

25 Por. En. Ps. 39, 16-17.

26 Por. Ev. Io. Tr. 32, 1; 61, 2.

27 Por. tamże, 50, 10. 
którzy Go krzyżowali. ${ }^{28}$ Biskup Hipony przypominał ponadto, że samo serce może być podzielone.

W komentarzach do różnych ksiąg Pisma Świętego Augustyn najczęściej pozostawał wierny terminologii biblijnej. W przypadku pojęcia cor był to wybór w pełni świadomy, gdyż pozwalał mu skorzystać z całego wachlarza znaczeń, w zależności od tego, jaki aspekt serca chciał podkreślić w określonej refleksji. Bogactwo semantyczne można wydobyć zwłaszcza z komentarzy Augustyna do psalmów i do pism Janowych. W Wyznaniach z kolei, oprócz całego bogactwa biblijnych znaczeń, można wyróżnić jeszcze jeden dodatkowy sens terminu „serce”. Chodzi mianowicie o najbardziej intymną cząstkę każdej osoby, gdzie rozgrywa się dramat egzystencji w całej jego wewnętrznej prawdzie. Jak swoisty manifest takiego znaczenia brzmią słowa, w których Augustyn tak mówi o swoim sercu: „Tylko w nim jestem taki, jaki naprawdę jestem". ${ }^{29}$

Analizując opisy doświadczeń osobistych i rozważania o charakterze duchowym, można zauważyć skłonność Augustyna do używania terminu cor. Dzięki niemu nie ograniczał się do sfery intelektualnej, ale mógł jednocześnie zawrzeć konotacje emocjonalne, uczuciowe, a nawet cielesne. Bardzo wymowną próbą połączenia języka biblijnego z filozoficznym jest opis wizji z Ostii. Augustyn, odtwarzając rozmowę o szczęściu ze swoją matką, Moniką, tuż przed jej śmiercią, użył wielu terminów zaczerpniętych z Plotyna (np. mens, intelligentia, cogitatio), ${ }^{30}$ ale w kulminacyjnym momencie zastosował słowo cor na oznaczenie najwyższej części duszy, która kontempluje samą Mądrość: „I gdy tak w żarliwej tęsknocie mówiliśmy o niej, dotknęliśmy jej na krótkie mgnienie całym porywem serca". ${ }^{31}$

28 Por. En. Ps. 37, 17-18.

29 Conf. X, 3.4: ,[cor meum,] ubi ego sum quicumque sum”; tłum. pol. W. K u b i a k, s. 220. Por. tamże, VIII, 8.19; 11.27; 12.28.

30 Por. P l o t y n, Enneady I, 6; V. Szerzej: P. H e n r y, La vision d'Ostie, J. Vrin, Paris 1938.

31 Por. Conf. IX, 10.24: „Et dum loquimur et inhiamus illi, attingimus eam modice toto ictu cordis"; tłum. pol. W. K u b i a k, s. 208. 
Augustyn usiłował zobrazować metaforyczny sens terminu cor dzięki wielu porównaniom, inspirowanym wyrażeniami biblijnymi. W symbolicznym znaczeniu ,serce” to np: rola Boża (En. PS. 58 (2), 1; 99, 2; Ev. Io. Tr. 3, 1); barka, na której zasypia Jezus (En. Ps. 34 (1), 3); świątynia Boga (Sermo 23, 7); dom/namiot Boga (En. Ps. 44, 23; 100, 4); ukryta izdebka, w której człowiek ma się modlić (En. Ps. 4, 6; 35, 5); szkatułka/skarbiec (En. Ps. 55, 19; 90 (2), 13; 123, 9); ołtarz (De Civitate Dei 10, 3.2).

Nadrzędnym celem powyższych porównań było ukazanie zamieszkiwania i działania Boga w człowieku. Natomiast w celu wyrażenia głębi i niepoznawalności serca Augustyn używał pojęcia „przepaść” (abyssus). ${ }^{32}$ Podkreślał, że nikt nie może do końca poznać nawet własnego serca, a tym bardziej wnętrza kogoś innego. Nawet u przyjaciela jest ono zasnute mgłą tajemnicy. ${ }^{33}$ Jedynie Bóg może je przeniknąć i zgłębić. ${ }^{34}$

\section{Serce - arcydzieło Trójjedynego Boga}

Augustyn wymalował w swoich pismach swoisty ,tryptyk serca” odpowiadający dogmatowi wiary w Trójcę Świętą. Serce, określone fundamentalnie przez relację do Boga, jest przez Stworzyciela powołane do istnienia, przez Chrystusa oświecone, przez Ducha Świętego nieustannie rozszerzane. Wobec serca Bóg jawi się zaś jako: Auctor, Doctor, Largitor suavitas intimae. ${ }^{35}$

Serce stworzone na „obraz Boga”

Prawda o stworzeniu człowieka na „obraz i podobieństwo Boże” ( $R d z 1,26-27)$ należy do podstawowych elementów antropologii chrześcijańskiej. Augustyn precyzował, że ten „obraz” znajduje się

\footnotetext{
32 Por. En. Ps. 41, 13-15.

33 Por. tamże, 55, 9.

34 Por. tamże, 7, 9; 39, 16. 23; Ev. Io. Tr. 13, 11; 44, 3; 46, 5.

35 Por. I. B o c h e t, Cor, s. 524-534.
} 
w sercu i dlatego jest ono uprzywilejowanym miejscem spotkania z Bogiem. ${ }^{36}$ Komentując werset Ps 33[32],15a: „On, który ukształtował każdemu z nich serce", podkreślił wyraźnie, że to sam Bóg w swojej łaskawości i miłosierdziu stwarza bezpośrednio każde serce, dzięki czemu jest ono wyjątkowe i niepowtarzalne. Te cechy nie negują oczywiście międzyludzkiej jedności, której pełnią jest uczestnictwo w jednym ciele Chrystusa. ${ }^{37}$

Augustyna utrzymywał, że Bóg zamieszkuje w sercu i podtrzymuje je w istnieniu. Nawet grzech nie jest w stanie całkowicie zniszczyć w człowieku „obrazu Boga”, choć może go zaciemnić i zniekształcić podobieństwo. ${ }^{38}$ To nie Bóg opuszcza człowieka, ale człowiek odgradza się od Boga. ${ }^{39}$ Stwórca pozostaje wierny i okazuje swą moc nawet wobec serca niewiernego, zamieszkując w jego przepastnej głębi. ${ }^{40}$ Dlatego droga nawrócenia wiedzie przez serce i odnowienie jego ikonicznego charakteru. ${ }^{41}$

Augustyn obalał twierdzenie, jakoby Bóg był przyczyną sprawczą niewiary i niewierności człowieka, jak mógłby to sugerować werset Iz 6, 10, sparafrazowany w J 12, 40. „Zatwardzanie serca” przypisane w tych wersetach działaniu Boga należy natomiast rozumieć jako wstrzymanie zwyczajnej pomocy i łaskawości wobec tego, kto jest uparty i zamknięty wewnętrznie. Ten nieustanny Boży osąd jest zakryty przed ludzkimi oczyma, ale zawsze sprawiedliwy, gdyż to zła wola człowieka jest powodem wewnętrznej ślepoty i niewiary. Augustyn zasugerował ponadto, że „zatwardziałość serca” mieści się jakoś w tajemnych planach zbawczych, w tym sensie, że skruszony grzesznik otrzymuje szansę, by się upokorzyć i zacząć poszukiwać Pana. ${ }^{42}$ Osobistą drogę i poszczególne etapy „kruszenia serca” opisał

\footnotetext{
36 Por. Ev. Io. Tr. 18, 10.

37 Por. En. Ps. 32 (3), 21.

38 Por. tamże, 4, 8; 57, 3.

39 Por. tami̇e, 99, 5.

40 Por. Ev. Io. Tr. 117, 5.

41 Por. En. Ps. 99, 5.

42 Por. Ev. Io. Tr. 53, 6-11.
} 
Augustyn w Wyznaniach, ukazując w nich nieustanne - choć tajemnicze - Boże prowadzenie.

\section{Serce odkupione i oświecone przez Chrystusa}

Augustyn bardzo często przypominał, że Bóg nie przestaje przemawiać do ludzkiego serca. ${ }^{43}$ Kluczowe miejsce w tym dialogu zajmuje wcielenie, które jest nie tylko wydarzeniem historycznym, ale stanowi też operatywną rzeczywistość duchową. Biskup Hippony był przekonany, że ludzkie kazania byłyby bezowocne, gdyby nie było wewnętrznego Nauczyciela, tj. Słowa, które w sercu każdego człowieka może stać się ciałem. ${ }^{44}$ Jako główne obrazy, ukazujące działalność wewnętrznego Nauczyciela, wskazywał Światło, które oświeca, i Źródło, które gasi pragnienie. W przeciwieństwie do wypisanego na sercu „obrazu Boga”, oświecenie wymaga zaangażowania woli i otwarcia serca.

Augustyn twierdził, że Chrystus - Prawda, jest obecny wszędzie i wszystkich oświeca, podobnie jak promienie słońca przenikają świat. Jednakże, podobnie jak ślepi nie widzą dnia, tak i nie wszyscy mają „oczy serca”, dzięki którym można zobaczyć światło prawdy. ${ }^{45}$ Uzdrowieniem wewnętrznego wzroku jest wiara w Słowo, które przyjęło słabość ciała. Dzięki wcieleniu, Chrystus może pomóc dotkniętemu ślepotą człowiekowi, tak by ten wreszcie zobaczył, to znaczy zrozumiał, prawdę Boskiego Słowa. ${ }^{46}$

43 Por. tamże, 22, 1; 39, 6; 40, 5.

44 Por. Ep. Io. Tr. 3, 13; Ev. Io. Tr. 97, 1. Szerzej: G. C o 11 i n i, Cristo Maestro interiore e cammino verso il Padre, w: La ricerca di Dio. La dimensione contemplativa della esperienza agostiniana. Corso Internazionale di Spiritualità, Roma 1-19 luglio 1979, Pubblicazioni Agostiniane, Roma 1981, s. 31-59; G. M a d e c, Saint Augustin et le maître intérieur, Connaissance des Pères de l'Église 48/1992, s. 16-20; I. B o c h e t, L'Écriture et le maître intérieur selon Augustin, Revue des sciences religieuses 72/1998, s. 20-37.

45 Por. Ev. Io. Tr. 35, 4; En. Ps. 57, 21-22.

46 Por. Ev. Io. Tr. 2, 16. 
Augustyn wyjaśniał znaczenie czerpania ze źródła Prawdy na przykładzie Ostatniej Wieczerzy. Jan, który spoczywa na piersi Mistrza, wyobraża człowieka, który czerpie z najgłębszych tajemnic Serca Jezusowego. Naczyniem jest pokora, która pozwala przeniknąć w intymne głębiny i pić z nich, jak ze źródła wody żywej. ${ }^{47}$

Biskup Hippony wielokrotnie podkreślał, że przemiana serca jest możliwa dzięki owocom Paschy Chrystusa. On wziął na siebie ludzką słabość, aby móc przemienić serce człowieka i uczynić je prawym. ${ }^{48}$ Ze swej strony człowiek, doświadczający burzy w swoim życiu, to znaczy uczuć gniewu, lęku, pożądliwości i innych pokus, powinien natychmiast zwrócić się do Chrystusa, obudzić tego, który zdaje się spać w barce serca, by uciszył groźne fale. ${ }^{49}$

\section{Serce rozszerzane przez Ducha Świętego}

Augustyn był w Kościele na Zachodzie jednym z najwybitniejszych autorów, którzy podjęli refleksję nad tajemnicą trynitarną. Problem relacji łaski i woli człowieka, a więc sposób działania Ducha Świętego w sercu człowieka rozwinął on przede wszystkim w tzw. sporze pelagiańskim. W wielu tekstach pochodzących z tego okresu przeciwstawiał nakazy Prawa wyryte na tablicach kamiennych, Prawu miłości wypisanemu na żywych sercach przez Ducha Bożego. ${ }^{50}$ Zasadnicza różnica między nimi dotyczy nie tyle treści, ile sposobu percepcji przez człowieka. Augustyn podkreślał, że przepisy starotestamentalne były wypełniane jedynie przez zewnętrzne akty, z obawy przed karą. Prawo Chrystusa ma natomiast charakter wewnętrzny. Podstawą refleksji Augustyna był werset Rz 5, 5: „Miłość Boża rozlana jest w sercach naszych przez Ducha, który został nam dany". Interpretując go, podkreślał, że Duch pociąga ku dobru,

\footnotetext{
47 Por. tamże, 18, 1.

48 Por. En. Ps. 31 (2), 26; 100, 6.

49 Por. Ev. Io. Tr. 49, 19; En. Ps. 108, 5.

50 Por. De Spiritu et Littera Liber Unus 17, 29 - 25, 42.
} 
a wypełnianie przykazania miłości w całej wolności serca, przynosi mu dar Boskiej słodyczy.

Wiele rozważań Augustyn oparł na grze słów: delectatio - dilectio. Zauważał np., że gdy serce człowieka jest wypełnione duchową miłością, to jego dobre czyny nie pochodzą z przymusu (invitus), ale są dobrowolne (voluntate), a nawet sprawiają przyjemność (voluptate). Miłość jest zatem darem Ducha, który rozszerza serce, obdarza je bezpieczeństwem i zdolnością do czynienia dobra. Tak rozumiana miłość rozszerza serca, bo Bóg czyni je zdolnym do miłowania nawet nieprzyjaciół. ${ }^{51}$

Serce, jako symbol wewnętrznego człowieka, jest nierozerwalnie związane z wolą. W systemie etycznym Augustyna centralne miejsce zajmuje miłość. Jedynie akty i uczucia wypływające z miłości, a nie z lęku, uznaje on za pochodzące z głębi serca. Dlatego Bogu należy ofiarować swoją wolę, gdyż On nie żąda krwawych ofiar, ale serca. ${ }^{52}$ W tym sensie proces rozszerzania serca trwa do końca życia. Niepokój serca jest znakiem dążenia ku pełni przeznaczenia, to znaczy odpoczynku i ukojenia, który może znaleźć tylko w Bogu. ${ }^{53}$

\section{Droga doskonalenia serca}

Potrójnej aktywności Trójjedynego Boga odpowiada wewnętrzna dynamika zranionego grzechem człowieka, określona przez trzy ruchy serca: tułaczkę na zewnątrz (foris), wejście wewnątrz siebie (intus), wznoszenie się ponad siebie (supra). ${ }^{54}$ Te trzy etapy są indywidualną odpowiedzią na uprzednie i zbawcze działania Boga, a mianowicie: stworzenie, oświecenie i uświęcanie.

51 Por. Ep. Io. Tr. 10, 6-7. Szerzej na temat działania Ducha Świętego w historii świata i człowieka u Augustyna, por. N. C i p r i a n i, Lo Spirito Santo, Amore che unisce. Pneumatologia e spiritualità in Agostino, Città Nuova, Roma 2011, s. 94-196.

52 Por. En. Ps. 134, 11.

53 Por. Conf. I, $1,1$.

54 Por. En. Ps. 41, 7-8; Ev. Io. Tr. 20, 11-13. 


\section{Z zewnętrznej tułaczki do wnętrza serca}

Augustyńska duchowość jest pochodną jego antropologii, której fundamentem jest przekonanie o zamieszkiwaniu Boga w sercu człowieka. Z tego osobistego doświadczenia, oczyszczonego i ugruntowanego przez refleksję filozoficzną i teologiczną, wyrasta przekonanie, że Boga można znaleźć przede wszystkim w najbardziej osobistym zakątku serca. On zawsze tam jest, nawet wtedy, gdy człowiek uczynił je pustkowiem. ${ }^{55}$

Augustyn był głęboko przekonany, że droga do Boga wiedzie nie tyle przez zewnętrzny świat, ile przez wnętrze człowieka. „Najpierw wróć do twego serca". ${ }^{56}$ Nie chodzi tu oczywiście o zwykłą uczuciowość, ale o zaangażowanie najgłębszej podmiotowości. Tylko człowiek świadomy siebie może przeżyć spotkanie z Bogiem. Autor Wyznań tak opisuje lata własnego błądzenia: „A gdzież byłem ja, gdy szukałem Ciebie? Ty byłeś tuż przede mną, ja zaś odszedłem nawet i od samego siebie. Nie mogłem siebie odnaleźć. Jakże miałbym znaleźć Ciebie?" 57

Główną przeszkodą na drodze do Boga, jest według biskupa z Hippony, życie poza sobą. Owszem, cały świat stworzony naprowadza na Boga, ,wielbi Boga”, ale tylko człowiek został stworzony na Jego obraz i podobieństwo. A zatem, wchodząc do swojego serca, doświadczając siebie i prawdy o sobie, człowiek odkrywa rzeczywistość większą od siebie i może doświadczyć prawdziwie intymnej obecności Boga: „Ty byłeś bardziej wewnątrz mnie niż to, co we mnie było

55 Por. Conf. V, 2.2; En. Ps. 74, 9.

56 Ev. Io. Tr. 18, 10: „Primo redi ad cor tuum”, tłumaczenie polskie w: Ś w. A u g u s t y n, Homilie na Ewangelię i Pierwszy List św. Jana, tłum. W. S z o ł d r s k i, W. K a n i a, PSP 15/1, Warszawa 1977, s. 270.

57 Conf. V, 2, 2: „Et ubi ego eram, quando te quaerebam? Et tu eras ante me, ego autem et a me discesseram nec me inveniebam: quanto minus te!"; tłum. pol. W. Ku bi a k, s. 86 . 
najbardziej osobiste, a zarazem wyżej nade mną, niż mogłem myślą sięgnąć kiedykolwiek". 58

Augustyn jest świadomy, że stanięcie wobec prawdy swojego serca, zwłaszcza wtedy, gdy jest ona gorzka i bolesna, jest działaniem wbrew spontanicznym impulsom i odruchom ucieczki w łatwiznę zapomnienia. Porównując serce do „wewnętrznego domu” (domus interior) tak pisze: „Kto ten dom ma zły, wypędza go zeń na zewnątrz. Kogo bowiem w sercu gniecie własne sumienie, podobnie jak komu leje się na głowę w jego domu, albo dym gryzie, nie znosi mieszkania w takim domu, tak też, kto nie ma serca spokojnego, nie może chętnie zamieszkiwać w swoim sercu" ${ }^{59}$ Konsekwencją żałosnego stanu wewnętrznego jest tendencja do życia na zewnątrz siebie i szukania radości „w wolnych zajęciach, w widowiskach, w rozpuście i wszelkim złu". ${ }^{60}$ Augustyn przestrzega przed złudnym uśpieniem czy też zamroczeniem serca przez przemijające przyjemności czy praktyczny ateizm. ${ }^{61}$ Pojawiający w takim stanie niepokój uznaje za jak najbardziej pożądany. „Niespokojne serce” zmusza bowiem do poszukiwania i otwiera drogę ku nawróceniu.

Powrót do siebie samego, do życia wewnątrz, stanowi fundamentalny krok w drodze do Boga. Wymaga to jednak odwagi i samozaparcia, walki wydanej łatwiźnie i konformizmowi. Augustyn jest świadom tego trudu, którego zresztą sam doświadczył. Dlatego nie mami tanimi obietnicami, ale mądrze do niego przygotowuje: „Ażeby jednak się poznać, trzeba długo przyzwyczajać się do uciekania od

58 Tamże, 6.11: „Tu autem eras interior intimo meo et superior summo meo”, tłum. pol. tamize, s. 52 .

59 En. Ps. 100, 4: „Hanc domum quisquis habet malam, pellitur ab illa foras. Quisquis enim in corde premitur mala conscientia, quomodo quisque ab stillicidio exit de domo sua, aut a fumo, non ibi se patitur habitare: sic qui non habet quietum cor, habitare in corde suo libenter non potest”, tłum. pol. J. S u lo w s k i, s. 337.

60 Tamże: „Tales foras exeunt a seipsis animi intentione, et de his quae foris sunt circa corpus delectantur; quietem in nugis, in spectaculis, in luxuriis, in omnibus malis quaerunt".

${ }^{61}$ Por. En. Ps. 106, 4. 
zmysłów, do skupiania swego umysłu i zamykania go w sobie". ${ }^{62}$ Podjęcie trudu wewnętrznej integracji jest jednak konieczne, gdyż w stanie nieładu i bez odpowiedniego usposobienia serca nie można zbliżyć się do prawdy. ${ }^{63}$

\section{Uzdrowienie wewnętrzne: z grzechu ku prawości}

Według Augustyna, chrześcijanin jest wezwany, by być człowiekiem zintegrowanym wewnętrznie, dojrzałym emocjonalnie i moralnie. Dlatego wejście w siebie to wprawdzie krok milowy, ale stanowiący dopiero początek drogi. Człowiek, który podejmuje podróż do własnego serca, decyduje się na stanięcie wobec Prawdy. W obliczu Boga odkrywa swoją niezbywalną godność i najbardziej wzniosłe powołanie, ale jednocześnie poznaje własną małość i uwikłanie w zło. Doświadczenie rozdwojenia czy też rozdarcia serca staje się w ten sposób początkiem drogi nawrócenia, czyli integracji wnętrza i jego głębokiego uzdrowienia. ${ }^{64}$ „Niech więc całym naszym zajęciem na tym świecie będzie uzdrowienie owego oka serca, dzięki któremu widzimy Boga". ${ }^{65}$

Bardzo liczne w pismach Augustyna odwołania do rzeczywistości serca, wyrażonej także za pomocą jego synonimów, czynią prawie niemożliwą jej wyczerpującą klasyfikację. Bardzo wyraźnie natomiast jawi się antytetyczny podział dyspozycji serca ze względu na

${ }^{62}$ A u g u s t i nu s, De Ordine Libri Duo I, 1.3: „Qui tamen ut se noscat, magna opus habet consuetudine recedendi a sensibus, et animum in seipsum colligendi atque in seipso retinendi"; tłumaczenie polskie w: Ś w. A u g u s t y n, O porzadku, w: t e n ż e, Dialogi filozoficzne, tłum. J. M o d r z e j e w s k i, I.W. Pax, Warszawa 1953, s. 148.

63 Por. A ug u s t i nu s, De Agone Cristiano Liber Unus 13.14.

64 Por. G. Gille t t e, Purity of Heart, s. 178-183.

65 Sermo 88, 5.5: „Tota igitur opera nostra, fratres, in hac vita est, sanare oculum cordis, unde videatur Deus"; tłumaczenie polskie w: J. G a r c i a, Św. Augustyn albo głos serca, tłum. P. R a k, Wyd. M, Kraków 1998, s. 123. 
kryterium jego zgodności z wolą Bożą. ${ }^{66}$ Jednym z najważniejszych rozróżnień to: serce prawe (cor rectum) i serce nieprawe (cor non rectum / distortum / pravum / curvum) ${ }^{67}$ Augustyn wskazuje też na serce rozdwojone (duplex) i proste (simplex) ${ }^{68}$ oraz nieczyste (immundum) i czyste (mundum) ${ }^{69}$ itp. Stan serca ujawnia się szczególnie w chwili próby. Człowiek nieprawego serca, napotykając nieprzewidziane trudności, zaczyna oskarżać Boga i negować Jego Opatrzność, zamiast przyjąć w pokorze Jego wolę, jak uczynił to Dawid przeklinany przez syna Gery, Szimei, pochodzącego z rodu Saula. ${ }^{70}$

Augustyn, przywołując obraz wypaczonej deski, która nie przystaje do prostej podłogi, chce zilustrować niemożność dopasowania się cor distortum do prawości Boga. ${ }^{71} \mathrm{~W}$ ostrych słowach krytykuje ludzi nieprawego serca, pragnących nagiąć przykazania Boga do własnych planów i decyzji. „Jego chcieliby poprawiać. Mało, że nie chcą pozwolić się Jemu poprawić". ${ }^{72}$ Nieprawość chrześcijan ma najczęściej formę zawoalowaną, z obawy przed społecznym potępieniem czy pogardą. Tacy ludzie żyją jednak w wewnętrznym kłamstwie, w swoistej duchowej schizofrenii. Ich serce jest rozdwojone (cor duplex), gdyż deklarują przynależność do Chrystusa, ale zostawiają też miejsce diabłu, np. przez praktykę zabobonów, magii, wróżb itp. ${ }^{73}$ Pociąg do przyjemności cielesnych i ziemskiego bogactwa czyni serce twardym i ociężałym. ${ }^{74}$ Nie ma ponadto współbrzmienia między sercem a wargami. ${ }^{75}$ Wezwanie do zgodności mowy i gestów ciała

${ }^{66}$ Por. B. K ró 1, ,,Serce” w „Enarrationes in Psalmos” św. Augustyna, Studia Sandomierskie 11 (2004) z. 3, s. 77-79.

67 En. Ps. 31 (2), 25; 44, 17; 77, 21; 93, 19; 100, 6.

68 Por. tamże, 133, 3; De Sermone Domini in Monte II (liczne, dalej: S. Dom. M.); De Mendacio Liber Unus 3, 3.

69 Por. Sermo 19, 3.

70 Por. En. Ps. 50, 15; Ev. Io. Tr. 25, 17; 28, 7.

71 Por. En. Ps. 44, 17.

72 En. Ps. 124, 2: „Corrigere illum volunt: parum est quia corrigi ab eo nolunt”; tłum. pol. J. S u low s k i, s. 4.

73 Por. Ev. Io. Tr. 7, 7.

74 Por. En. Ps. 4, 3; Ev. Io. Tr. 1, 7.

75 Por. En. Ps. 74, 9. 
$\mathrm{z}$ prawdą serca jest $\mathrm{w}$ istocie zaproszeniem do interioryzacji wiary. Augustyn podkreśla, że nie wystarczy zewnętrzne manifestowanie znaków wiary, np. krzyża, ale trzeba wcześniej naznaczyć nim serce, to znaczy umiłować pokorę. ${ }^{76}$

Cor rectum natomiast, niezależnie od tego, czy wola Boża jest słodka (dulcis) czy gorzka (aegrotas), zawsze się z nią zgadza. ${ }^{77} \mathrm{Nie}$ chodzi tu wyłącznie o decyzje i czyny, choć te są kluczowe w ocenie stanu serca. Także w sferze pragnień dochodzi do swoistej harmonii. Serce prawe szuka Boga dla Niego samego, a nie dla korzyści czy nagrody. ${ }^{78}$ Jest ono zintegrowane, a jego prostota wyraża się w poszukiwaniu dobra w każdym czynie. ${ }^{79}$ Nie zważa na ludzkie pochwały, a kieruje się jedynie osądem sumienia, ufając, że Bóg je kiedyś nagrodzi ${ }^{80}$ Mamy tu do czynienia ze swoistą synergią, gdyż szukanie Boga skutkuje oczyszczaniem serca. „Przylgnij zatem sercem do Niego, a serce twe stanie się prawe". ${ }^{81}$

Zarówno przemyślenia i obserwacje, jak i osobiste doświadczenie, skłaniały Augustyna do przeświadczenia, że serce jest kolebką złych myśli, wyobrażeń i pragnień. ${ }^{82} \mathrm{Na}$ podstawie jego pism można sporządzić długą listę „,chorób serca”, których wspólnym mianownikiem jest niemożność poznawania rzeczywistości boskich. Dlatego czystość serca, polegająca na oglądaniu Boga, jest nie tyle stanem, ile pragnieniem.

Człowiek nie jest w stanie osiągnąć na ziemi prawdziwego pokoju serca. Nawet gdy chce być dobry to często ogarniają go różnorakie rozterki i pokusy. Serce jest zatem terenem walki. ${ }^{83}$ Niejako wbrew woli, złe myśli i uczucia w jakiś sposób przedostają się do niego.

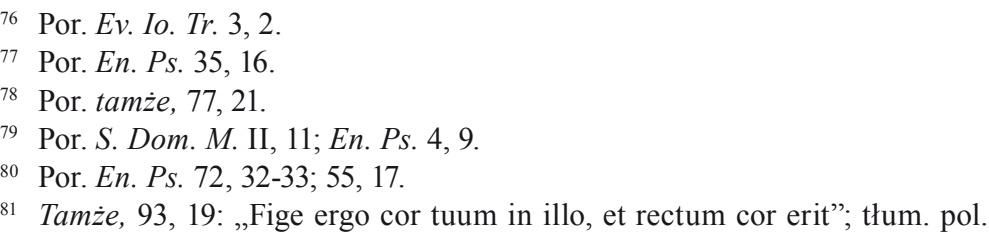

J. S u low s ki, s. 243.

82 Por. tamże, 102, 6.

83 Por. tamże, 99, 11. 
Trzeba z nimi wytrwale walczyć, co niesie ze sobą możliwość zranień i wewnętrznego cierpienia. Celem zobrazowanie tych gwałtownych uczuć, które zalewają serce człowieka dobrego, Augustyn odwoływał się do epizodu burzy na jeziorze (por. Mk 4, 35-41). W jego metaforycznej interpretacji ,wiatr” symbolizuje niesprawiedliwe inwektywy, natomiast „fale, zalewające barkę” - to gniew i chęć odwetu, które opanowują serce. ${ }^{84}$ Biskup Hippony podkreślał, że jedynym ratunkiem, by nie ulec pokusie odpowiedzenia złem na zło, jest ,zbudzenie Chrystusa”, czyli odwołanie się do wiary, ${ }^{85}$ bo tylko ona otwiera serce na przyjęcie łaski. ${ }^{86}$

Istotnie, Chrystus to medicus interior, ${ }^{87}$ który leczy wszelkie słabości i wyrywa z serca nieprawość, nie łamiąc przy tym wolnej woli pociągniętej najwznioślejszą słodyczą. ${ }^{88}$ Uzdrowienie serca, to znaczy pokonanie przewlekłej choroby grzechu, nie jest jednak końcem procesu uświęcenia. Ostateczny cel człowieka jest nieskończenie wznioślejszy i wykraczający poza niego samego: „Wejdź w serce, a stamtąd do Boga". ${ }^{89}$

Oto najważniejszy i ostateczny krok w augustiańskiej duchowości. Człowiek nie jest powołany do osiągnięcia swego rodzaju doskonałości humanistycznej, ale do zjednoczenia z Bogiem. Ten kluczowy punkt myśli Augustyna, niejako jego osobisty manifest, znajduje swój wyraz już w jednym z pierwszych dzieł, Solilokwiach, stanowiących zapis wewnętrznego dialogu: „Oto modliłem się do Boga. «Co chcesz zatem poznać?» (...) Chcę poznać Boga i duszę. «Czy nic więcej?»

84 Por. tami̇e, 54, 10; 108, 5.

85 Por. Ev. Io. Tr. 49, 19.

86 Por. tamże, 39, 3.

87 Por. R. A r b e s m a n n, The Concept of ,,Christus medicus” in St. Augustine, Traditio. Studies in ancient and medieval history, thought and religion 10/1954, s. 1-28; t e n ż e, Christ, the „Medicus humilis” in St. Augustine, w: Augustinus Magister, t. 2, Paris 1954, s. 623-629.

88 Por. Conf. IX, 1.1.

89 Sermo 311, 14.13: „Redi ad cor, et inde ad Deum”; tłumaczenie polskie w: Ś w. A u g u s t y n, Wybór mów, tłum. J. J a w o r s k i, PSP 12, Warszawa 1973, s. 175. 
Nic zgoła". ${ }^{90} \mathrm{Z}$ tego osobistego pragnienia wyrosła jedna $\mathrm{z}$ najbardziej znanych modlitw: „Boże zawsze niezmienny! Spraw, abym poznał siebie, spraw, abym poznał Ciebie". ${ }^{91}$

Te dwie rzeczywistości: Bóg i człowiek, są zawsze złączone. Augustyn badał serce człowieka, by poznać Boga; próbował zaś poznać Boga, aby zrozumieć człowieka. Transcendencja Boga jest zawsze złączona z Jego immanencją. Bóg jest Istnieniem, dlatego ze swej natury przekracza wszystko; ale jest też Mocą Stwórczą i dlatego, ze swej natury, jest obecny wszędzie, zwłaszcza w człowieku. Jest obecny i nieobecny zarazem: ponieważ obecny człowiek Go poznaje, a nieobecny - wciąż Go szuka.

Filozoficzna refleksja i doświadczenie wiary doprowadziły Augustyna do punktu, w którym te dwie rzeczywistości najpełniej się spotykają, punktu, w którym ludzki rozum zostaje ogarnięty światłem objawienia. Tym punktem jest Chrystus - Jednorodzony obraz Boga niewidzialnego, Bóg, który stał się człowiekiem. Augustyn wyznał: „Myślałem o tym, skąd powinienem nabyć mocy, która by mi umożliwiła radowanie się Tobą. Nie znajdowałem na to żadnego sposobu, dopóki nie wyciągnąłem rąk ku Pośrednikowi między Bogiem a ludźmi, człowiekowi Jezusowi Chrystusowi, który jest wzniesionym ponad wszystko Bogiem błogosławionym na wieki". ${ }^{22}$

Zbawcza rola Chrystusa, według Augustyna, polega nie tylko na tym, że pokonał grzech i odkupił cały świat, ale, że jest tym, który ma moc przemienić serce każdego człowieka. „Chrystus narodził się,

90 A u g u s t i n u s, Soliloquiorum Libri Duo I, 2.7: „Ecce oravi Deum. Quid ergo scire vis? Deum et animam scire cupio. Nihilne plus? Nihil omnino"; tłumaczenie polskie w: A u g u s t y n, Solilokwia, tłum. A. Ś w i d e r k ó w n a, Warszawa 2010, s. 19.

91 Soliloquiorum Libri Duo II, 1.1: „Deus semper idem, noverim me, noverim te"; tłum. pol. tamże, s. 46.

92 Conf. VII, 18.24: „Et quaerebam viam comparandi roboris, quod esset idoneum ad fruendum te, nec inveniebam, donec amplecterer mediatorem Dei et hominum, hominem Christum Iesum, qui est super omnia Deus benedictus in saecula"; tłum. pol. W. K u b i a k, s. 156. 
niech nikt nie wątpi, że się nie odrodzi w nim”. ${ }^{93}$ Opis tego „Bożego Narodzenia" w sercu Augustyna stanowi jedną z najpiękniejszych kart jego Wyznań, kart pełnych zachwytu i gorącego pragnienia Boga: „Późno Cię umiłowałem, Piękności tak dawna a tak nowa, późno Cię umiłowałem. W głębi duszy byłaś, a ja się błąkałem po bezdrożach i tam Ciebie szukałem, biegnąc bezładnie ku rzeczom pięknym, które stworzyłaś. Ze mną byłaś, a ja nie byłem z Tobą. One mnie więziły z dala od Ciebie - rzeczy, które by nie istniały, gdyby w Tobie nie były. Zawołałaś, rzuciłaś wezwanie, rozdarłaś głuchotę moją. Zabłysnęłaś, zajaśniałaś jak błyskawica, rozświetliłaś ślepotę moją. I oto rozlałaś woń, odetchnąłem nią - i oto dyszę pragnieniem Ciebie. Skosztowałem - i oto głodny jestem, i łaknę. Dotknęłaś mnie - i zapłonąłem tęsknotą za pokojem Twoim". ${ }^{94}$

Powrót do serca i odkrycie tam Niestworzonego Piękna zapoczątkowuje długą drogę upodobnienia serca do obrazu Boga. W Kazaniu 20, ${ }^{95}$ Augustyn udziela wskazówek, opierając się na Ps 50, 12: „Stwórz, Boże, we mnie serce czyste”. Podkreśla, że autor psalmu jest człowiekiem, który upadł, odczuwa skruchę i pragnie odzyskać utraconą nadzieję. Nie usprawiedliwia swojego grzechu, nie przerzuca winy na innych, ale błaga o wielkie miłosierdzie. „Wielka rana wymaga wielkiego lekarstwa". ${ }^{96}$ Dlatego trzeba stawać w prawdzie,

93 Sermo 189, 3: „Nemo dubitet renasci, Christus natus est”; tłum. pol. J. J a w o r s k i, s. 38.

94 Conf. X, 27.38: „Sero te amavi, pulchritudo tam antiqua et tam nova, sero te amavi! Et ecce intus eras et ego foris et ibi te quaerebam et in ista formosa, quae fecisti, deformis irruebam. Mecum eras, et tecum non eram. Ea me tenebant longe a te, quae si in te non essent, non essent. Vocasti et clamasti et rupisti surditatem meam, coruscasti, splenduisti et fugasti caecitatem meam; fragrasti, et duxi spiritum et anhelo t ibi, gustavi, et esurio et sitio, tetigisti me, et exarsi in pacem tuam", NBA I, 332; tłum. pol. W. K u b i a k, s. 246.

95 Sermo 20; tłumaczenie polskie w: A u g u s t y n, Kazanie 20: „Stwórz we mnie, o Boże, serce czyste”, tłum. E. K ol b u s, Vox Patrum 17(1997) z. 32-33, s. $469-474$.

96 Sermo 20, 2: „Magnam medicinam magnum vulnus desiderat”, w: NBA XXIX, Città Nuova, Roma 1979, s. 370; tłum. pol. tamże, s. 470. 
niejako postawić się przed trybunałem własnego serca i potępić własny grzech.

Augustyn wskazuje na trzy pokusy i niebezpieczeństwa rodzące się w sytuacji po grzechu: samousprawiedliwienie lub przerzucenie winy na kogoś lub na coś innego; rozpacz, tzn. utrata nadziei na przebaczenie; pobłażliwość lub przesadna nadzieja, tzn. przekonanie, że Bóg zawsze wybacza, nawet bez skruchy serca i chęci poprawy.

Takie postawy serca prowadzą jednak do dalszego rozpalenia namiętności i wszelkich grzesznych czynów. Świadomy tego Augustyn poszukiwał bezpiecznego miejsca, by uniknąć pułapki wiodącej ku zagładzie. ${ }^{97}$ Jego zdaniem, jest nim natychmiastowa skrucha i wołanie serca o przebaczenie, którego Bóg chętnie udziela. „Łatwiej wstaniesz, jeśli cię podniesie, ponieważ nie upada. Zstąpił bowiem ku tobie Ten, który nie upada". ${ }^{98}$

\section{Rozszerzanie serca dla miłości Boga}

Droga wewnętrznego doskonalenia nie kończy się na powrocie do serca i jego zintegrowaniu. Augustyn nie jest piewcą duchowego narcyzmu czy - mówiąc językiem psychologii - zatapiania się w podmiotowej jaźni. Wezwanie, by powrócić do siebie, nie jest zaproszeniem do egotycznego chocholego tańca wokół własnych planów, problemów, zmartwień, oczekiwań i nadziei. Kolejnym etapem, który na ziemi się zaczyna, ale nigdy się nie kończy, jest zbliżanie się do Boga: „Wróćcie do serca; dlaczego odchodzicie od siebie i gubicie się przez was? Dlaczego chodzicie po samotnych drogach? Błądzicie, włócząc się, powróćcie. Do kogo? Do Pana". 99

97 Por. tamże, 4.

98 En. Ps. 95, 7: „Melius surgis, si te ille erigat qui non cadit. Descendit enim ad te ille qui non cadit"; tłum. pol. J. S u low s k i, s. 274.

${ }^{99}$ Ev. Io. Tr. 18, 10: „Redite ad cor: quid itis a vobis, et peritis ex vobis? quid itis solitudinis vias? Erratis vagando; redite. Quo? Ad Dominum"; tłum. pol. W. S z ołdrs k i, W. K a n i a, s. 269-270. 
Ostatecznym celem, a zarazem nagrodą dla każdego, kto kochał Boga sercem czystym, będzie zjednoczenie z Bogiem i ujrzenie Go takim, jaki jest. ${ }^{100}$ Pełny stan czystości serca zostanie osiągnięty dopiero w eschatonie. Na ziemi jego doskonałość jest nieustannym pragnieniem. Dlatego serce powinno być stale oczyszczane przez modlitwę i karmione słowem Bożym oraz podążać ścieżką pokory. W ten sposób zostaje przygotowane do przyjęcia Chrystusa: „Oczyśćcie serce, aby On je oświecił i wszedł Ten, którego wzywacie. Niech będzie Jego domem, a On będzie Twoim. Zamieszka w tobie, a ty zamieszkasz w nim". ${ }^{101}$ Oczyszczone z grzechu serce staje się mieszkaniem Boga: „Gdzie Bóg mieszka, jeśli nie w swojej świątyni? Czym jest Jego świątynia? Tworzą ją ściany? Broń Boże. (...) Gdzie zostanie objęty? W duszy mającej pokój, w duszy sprawiedliwej. Ona Boga nosi". ${ }^{102}$

Stała obecność Boga w sercu jest owocem wiary, która działa przez miłość. ${ }^{103}$ Gdy wiara jest silna, owocuje pokojem, gdy słabnie i ,zasypia” zrywają się burze i niepokoje. Augustyn, zwłaszcza w kontekście kontrowersji pelagiańskiej, podkreślał pierwszeństwo Bożej łaski. Wskazywał na Ducha Świętego, jako tego, który zawsze przewodzi i towarzyszy człowiekowi w jego postępie duchowym, pomaga pokonać słabości, wzmacnia siły i prowadzi go do świętości, która jest miłością płynącą z czystego serca, dobrego sumienia i wiary nieobłudnej $(1 \mathrm{Tm} 1,5)$. Uważał nawet, że taka miłość nie skończy się wraz ze śmiercią, ale będzie ciągle wzrastać, gdyż to Duch Święty jest jej niewyczerpalnym źródłem. ${ }^{104}$

${ }^{100}$ Por. En. Ps. 55, 17.

${ }^{101}$ Tamże, 30 (4), 8: „Purgate cor, ut ipse illuminet, et quem invocatis intret. Esto domus eius, et erit domus tua: habitet in te, et tu habitabis in eo"; thum. pol. J. S u 1 ow s k i, s., 265.

${ }^{102}$ Tamże, 92, 6: „Ubi habitat Deus, nisi in templo suo? Quod est templum eius? Parietibus instruitur? Absit. (...) Et ubi capitur? In anima quieta, in anima iusta: ipsa illum portat"; tłum. pol. tamże, s. 218.

${ }^{103}$ Por. tamze, 108, 32; Sermo 53, 10.11.

${ }^{104}$ Por. A u g u s t i n u s, De Natura et Gratia Liber Unus 70, 84. 
Troska o wykazanie uprzedzającej łaskawości Boga wobec ludzkich zasług przebija też z komentarzy do Psalmu 118. Analizując werset 32, Augustyn mówił o poszerzeniu serca (dilatatio cordis): „Rozszerzenie serca to rozkosz sprawiedliwości. Jest to dar Boży, żebyśmy w zachowaniu jego przykazań nie kierowali się obawą kary, ale miłością i rozkoszą sprawiedliwości". ${ }^{105}$ Podkreśla, że człowiek nie własną mocą i nie o własnych siłach pomnaża dobro. To sam Duch Święty, który jest miłością, wypisuje Prawo Boże w sercach ludzkich. Nie ma ono charakteru zewnętrznych nakazów, których trzeba się nauczyć na pamięć, ale jest wewnętrznym nakazem, który przekłada się na konkret życia. Biskup Hippony wielokrotnie akcentował rolę miłości, która rozszerza serce, w przeciwieństwie do lęku, który je zasklepia. ${ }^{106}$ Za pozbawione sensu uznawał obawy o to, by przychodzący do serca Duch Święty nie ograniczył jego przestrzeni. Nie jest On przecież intruzem ani despotą. Nie niszczy wolności człowieka, ale wręcz ją pomnaża. Kiedy bowiem wyrywa smutek z serca, poszerza je i wypełnia radością. ${ }^{107}$

Serce przepełnione miłością, to znaczy Duchem Świętym, jest otwarte i rozszerzone. ${ }^{108}$ Jednak ze względu na przeszły stan może doświadczać skrupułów. ${ }^{109}$ Wyrzuty sumienia unaoczniają wyraźnie, z jak wielkim trudem i bólem związane jest postępowanie w świętości. Jest ono nieustannym pielgrzymowaniem, wchodzeniem na szczyt po ścieżce prawdy i pokory. W komentarzach do psalmów gradualnych, napisanych w latach 406-406, Augustyn opisał wznoszenie się serca, począwszy od doliny płaczu, która symbolizuje konieczność

${ }^{105}$ En. Ps. 118 (10), 6: „Cordis dilatatio, iustitiae est delectatio. Haec munus est Dei, ut in praeceptis eius non timore poenae angustemur, sed dilectione, et delectatione iustitiae dilatemur"; tłum. pol. J. S u 1 o w s k i, s. 249.

106 Por. tamże, 118 (11), 1.

${ }^{107}$ Por. Sermo 169, 12.15.

108 Por. En. Ps. 4, 6.

${ }^{109}$ Por. tamże, 45, 3-4. 
pokory, ku wysokościom samego Boga, objawionego w Chrystusie. ${ }^{110}$ Postęp na tej drodze jest owocem miłości, regres - skutkiem pychy. ${ }^{111}$

Koncepcja wznoszenia się duszy do Boga nie jest w myśli Augustyna jednolita. ${ }^{112} \mathrm{~W}$ pismach powstałych $\mathrm{w}$ pierwszych latach po nawróceniu jest ona bardzo mocno przesiąknięta terminologią filozoficzną. Po objęciu biskupstwa w Hipponie, fundamentem jego rozważań stało się zasadniczo Pismo Święte. Komentarze do Psalmów pisane w latach 392-418 odzwierciedlają bardzo wyraźnie jego ewolucję wewnętrzną. Nie jest możliwe, by w kilku zdaniach oddać całe bogactwo jego koncepcji ascetycznych i mistycznych. Spośród kluczowych wskazań Augustyna, odnośnie do rozwoju życia duchowego, wydaje się, że warto wyróżnić trzy, odpowiadające scharakteryzowanym wyżej elementom jego antropologii. Mam mianowicie na myśli modlitwę (oczyszczenie obrazu Bożego w sercu), pokorę (naśladowanie Chrystusa) i miłość (poddanie się kierownictwu Ducha Świętego). Te trzy kluczowe elementy życia chrześcijańskiego są ze sobą wewnętrznie powiązane i wzajemnie się warunkują.

\section{Modlitwa}

Augustyn nie pozostawił żadnego traktatu o modlitwie, choć za takowy można by uznać List 130: Do Proby. Najbardziej kompleksowym wyrazem jego refleksji, duchowych doświadczeń, medytacji, rozważania słowa Bożego są z pewnością Komentarze do Psalmów, pisane przez ponad ćwierć wieku. Wiele przykładów osobistej modlitwy zawartych jest natomiast w Wyznaniach.

Z pism biskupa Hippony wyłania się rzeczywistość modlitwy pojmowanej jako codzienny „,pokarm” chrześcijanina. ${ }^{113}$ Choć istnieją

${ }^{110}$ Por. tamże, 119, 1; 120, 1.

111 Por. tamże, 120, 5.

112 Por. F. Van F let e r e n, Ascesa dell'anima, w: A. D. F it z ge r a ld, Agostino: dizionario enciclopedico, s. 239-245.

${ }^{113}$ Szerzej R. W e a ve r, Preghiera, w: tamże, s. 1151-1156; T. A. H a n d, St. Augustine on Prayer, Newman Press, Westminster 1963; A.-M. B e s n a r d, Saint 
różne jej formy, to najbardziej wzniosłą stanowi uwielbienie. Ono jest jej prawdziwym celem, gdyż wyraża całkowite i bezinteresowne oddanie Bogu. ${ }^{114}$ Serce, dzięki takiej modlitwie, jest nieustannie oczyszczane od dawnych przywiązań, rozpalane miłością Boga i wypełniane pragnieniem wyśpiewywania radosnego alleluja przez całą wieczność. ${ }^{115}$ Augustyn podkreśla, że nie tylko wypowiadane słowa, ale już samo pragnienie Boga - nawet to nie do końca uświadomione - jest modlitwą. ${ }^{116}$ Choć Bóg zna potrzeby człowieka, wpierw nawet niż zostaną wypowiedziane, to jednak chce, ,aby w modlitwie ćwiczyło się nasze pragnienie, które pozwoli nam przyjąć dar". ${ }^{117} \mathrm{Nie}$ powinna być ona chaotyczna, ale systematycznie karmiona i formowana przez naukę Pisma Świętego. ${ }^{118}$ Jako wzór wskazuje Modlitwę Pańską, której poszczególne wezwania określają charakter i kierunki rozwoju chrześcijańskiej duchowości. ${ }^{119}$

\section{Pokora}

Modlitwa, karmiona słowem Bożym, jest nierozerwalnie związana $\mathrm{z}$ postawą pokory, ${ }^{120}$ która umożliwia autentyczne zachwycenie się pięknem Boga i poznanie prawdy swojego serca. Pokora jest konieczna nie tylko do przemiany życia, ale także do zgłębiania Pisma Świętego. Augustyn wyznaje, że to właśnie z powodu młodzieńczej

Augustin: Prier Dieu, Cerf, Paris 1964; G. A n t o n i, La prière chez saint Augustin. D’une philosophie du langage à la théologie du Verbe, J. Vrin, Paris 1997.

114 Por. S. Dom. M. II, 2, 15.

115 Por. Sermo 252, 9; En. Ps. 86, 9.

116 Por. En. Ps. 37, 14.

${ }_{117}$ Epistula 130, 8.17: „Exerceri in orationibus desiderium nostrum, quo possimus capere quod praeparat dare"; tłum. pol. P. R a k, s. 133.

118 Por. M. C a m e ro n (red.), Essential Expositions of the Psalms by Saint Augustine, New City Press, New York 2015, s. 17-24.

119 Por. Sermo 56, 3.4; Epistula 130, 11-12.

${ }^{120}$ Por. En. Ps. 74,2. Szerzej: D. W. R e d d y, Umiltà, w: A.D. F it z g e r a ld, Agostino: dizionario enciclopedico, s. 1414-1422; P. A n d è s, L'humilité à l'école de saint Augustine, Revue d'ascétique et de mystique 31/1955, s. 28-46; J. A. G a 1 i n d o R o d r i g o, La humilidad en san Agustín, Teología Espiritual 30/1986, s. 207-220. 
pychy nie był otwarty na mądrość zawartą w słowie Bożym: „W mej młodości starałem się zbliżyć do Pisma Świętego, jednak w zarozumiałej postawie (...). Przepełniony dumą szukałem tego, co można znaleźć jedynie w pokorze". ${ }^{121}$

Pierwszeństwo Boga na każdym etapie zbawczym, tak ogólnoludzkim, jak i indywidualnym, czyni z niej, według Augustyna, warunek sine qua non nie tylko duchowego rozwoju, ale w ogóle chrześcijańskiego życia jako takiego. ${ }^{122}$ Pokora ma poprzedzać, towarzyszyć i następować po każdym dobrym czynie. ${ }^{123}$ Jest cnotą wiodącą, gdyż naśladuje kenozę Chrystusa, która jest wzorem kształtowania się słowa Bożego w sercu człowieka. „Kto do Mnie przychodzi, pokornym się staje; kto Mnie się trzyma, pokornym będzie, ponieważ nie czyni swej woli, ale wolę Boga". ${ }^{124}$ Augustyn zapewnia o szczególnym wsparciu Zbawiciela dla podążających drogą uniżenia. ,Jeżeli się wywyższasz, [Bóg] odsuwa się od ciebie; jeśli się poniżasz, pochyla się nad tobą". ${ }^{125}$ Przestrzega jednocześnie przed niebezpieczeństwem pychy, ${ }^{126}$ a nawet jej wysublimowanej formy, jaką jest fałszywa pokora. Ta ostatnia bowiem jest postawą, która zatruwa dobre czyny ukrytym dla oczu poszukiwaniem własnej chwały. ${ }^{127}$ Tymczasem prawdziwa pokora, naznaczona solidarnością z bliźnimi, ma na celu uwielbienie Boga, który wywyższa swoich wiernych w stosownej chwili.

${ }^{121}$ Sermo 51, 5.6: „Cum primo puer ad divinas Scripturas ante vellem afferre acumen discutiendi (...). Superbus enim audebam quaerere, quod nisi humilis non potest invenire"; tłum. pol. P. R a k, s. 72.

122 Por. En. Ps. 31 (2), 11; Ev. Io. Tr. 15, 25; 81, 2.

${ }^{123}$ Por. Epistula 118, 3.22.

${ }^{124}$ Ev. Io. Tr. 25, 16: ,Qui ad me venit, humilis fit; qui mihi adhaeret, humilis erit; quia non facit voluntatem suam, sed Dei”; tłum. pol. W. S z ołd r s k i, W. K a n i a, s. 363.

${ }^{125}$ Sermo 21, 2: „Si extollis te, longe secedit a te; si humilias te, inclinat se ad te"; tłum. pol. P. R a k, s. 129.

${ }^{126}$ Por. En. Ps. 124, 1.

${ }^{127}$ Por. Epistula 118, 3. 22. 


\section{Miłość}

Augustyn chciał dotrzeć w swoich poszukiwaniach do najbardziej uniwersalnych prawd i podstawowych zasad, z których mógłby wyprowadzić wszystkie inne. I tak jak serce było dla niego symbolem wewnętrznego człowieka, tak miłość (amor, caritas, dilectio) - zasadniczą postawą wobec Boga, bliźnich i siebie samego. ${ }^{128}$ „Miłuj bliźniego i patrz w siebie, dlaczego kochasz bliźniego; tam ujrzysz Boga, na ile zdołasz". ${ }^{129}$ Według Augustyna, celem całego nauczania biblijnego jest wezwanie do budowania na miłości: „Celem i pełnią Prawa, jak i wszystkich ksiąg świętych jest miłość (...). Komu zatem wydaje się, że zrozumiał Pismo Święte całe, albo jego część, lecz nie wprowadza w życie owej podwójnej miłości Boga i bliźniego, ten jeszcze niczego nie pojął".130

W Chrystusie Bóg najpełniej objawił, że jest Miłością. Bez miłości jest niezrozumiały. Dlatego w wydaniu chrześcijańskim jest ona postawą tak fundamentalną, że warunkuje nawet właściwe poznanie. „Do prawdy się nie dochodzi inaczej, jak drogą miłości”. ${ }^{131}$ Miłość

${ }^{128}$ Por. T. J. V a n B a v e 1, Amore, w: A. D. F it z ge r a ld, Agostino: dizionario enciclopedico, s. 175-186; A. S o 1 ig n a c, La conception augustinienne de l'amour, Bibliothèque Augustinienne 14/1962, 617-622; S. K o w a $1 \mathrm{c} \mathrm{z} \mathrm{y} \mathrm{k,} \mathrm{Koncepcja} \mathrm{miłości}$ św. Augustyna jako węzłowej aktywizującej wartości życia ludzkiego, Vox Patrum 4(1984) t. 6-7, s. 187-207; R. C a n n i n g, The Unity of Love for God and Neighbour in St. Augustine, Heverlee-Leuven 1993.

${ }^{129}$ Ev. Io. Tr. 17, 8: „Dilige ergo proximum: et intuere in te unde diligis proximum; ibi videbis, ut poteris, Deum"; tłum. pol. W. S z ołd r s k i, W. K a n i a, s. 255.

${ }^{130}$ A u g u s t i nu s, De Doctrina Christiana Libri Quatuor I, 35, 39 - 36, 40 (dalej: Doctr. Chr.): „Legis et omnium divinarum Scripturarum plenitudo et finis esse dilectio. (...) Quisquis igitur Scripturas divinas vel quamlibet earum partem intellexisse sibi videtur, ita ut eo intellectu non aedificet istam geminam caritatem Dei et proximi, nondum intellexit"; tłumaczenie polskie w: Ś w. A u g u s t y n, O nauce chrześcijańskiej, tłum. J. S u 1 o w s k i, PSP 22, I. W. Pax, Warszawa 1989, s. 45 .

${ }^{131}$ Te n ż e, Contra Faustum Manichaeum Libri Triginta Tres 32, 18 (dalej: C. Faust.): „Non intratur in veritatem nisi per caritatem”; tłumaczenie polskie 
siebie samego jest naturalnym przykazaniem. ${ }^{132}$ Jednakże swoją podstawę i wypełnienie znajduje dopiero w miłości Boga z całego serca, do czego uzdalnia Chrystus. Analizując dynamikę Bożego Narodzenia, Augustyn podkreśla znaczenie otwartości i zaangażowania człowieka: „,[On] pragnie być twoim gościem, przygotuj Mu miejsce. Co znaczy: Przygotuj Mu miejsce? Nie miłuj siebie, ale Jego!"133

Miłość jest największym przykazaniem, dlatego że jednoczy serce z jej przedmiotem, tj. Bogiem samym, i pozwala uczestniczyć w Jego życiu. ${ }^{134}$ Ponieważ taki jest ostateczny cel człowieka, dlatego miłowanie Boga całym sercem jest prawdziwą miłością siebie samego. Egoizm, mimo pozornej troski o siebie, jest w istocie formą nienawiści siebie. ${ }^{135}$ Natomiast zaparcie się siebie dla Boga jest z kolei wyrazem miłości. ${ }^{136}$ Taka logika legła u podstaw kluczowej idei monumentalnego dzieła Augustyna, O Państwie Bożym: „Dwie miłości więc powołały dwa państwa: miłość własna, posunięta aż do pogardy Boga, powołała państwo ziemskie; miłość Boga zaś posunięta aż do pogardzania sobą powołała państwo niebieskie". ${ }^{137}$

Miłość nie jest dla Augustyna wzniosłym uczuciem ani też postawą uduchowionego egocentryzmu, który karmi się pychą odzianą w szatę pobożności. Prawdziwa miłość jest otwarta na bliźniego i sprawdza się w konkretach życia. Chociaż miłowanie Boga jest pierwsze w porządku nakazów (ordo praecipiendi), to miłość bliźniego ma priorytet

w: Ś w. A u g u s t y n, Przeciw Faustusowi, tłum. J. S u 1 o w s k i, PSP 56, Warszawa 1991, s. 139.

132 Por. C. Faust. 21, 5; Doctr. Chr. I, 24, 24.

${ }^{133}$ En. PS. 131, 6: „Hospitari apud te vult; fac illi locum. Quid est, fac illi locum? Noli amare teipsum, illum ama"; tłum. pol. J. S u 1 ow s k i, s. 90.

${ }^{134}$ Por. Ep. Io. Tr. 8, 14.

${ }^{135}$ Por. En. Ps. 11, 5; De Trinitate Libri Quindecim XIV 14.18.

${ }_{136}$ Por. Ev. Io. Tr. 51, 10.

${ }^{137}$ De Civitate Dei Contra Paganos Libri XXII 14, 28: „Fecerunt itaque civitates duas amores duo, terrenam scilicet amor sui usque ad contemptum Dei, caelestem vero amor Dei usque ad contemptum sui"; tłumaczenie polskie w: Ś w. A u g u s t y n, O Państwie Bożym: przeciw poganom ksiag XXII, tłum. W. K o r n a t o w s k i, Warszawa 1977, t. 2, s. 162. 
w wykonaniu (ordo faciendi). ${ }^{138}$ Opierając się na teologii św. Jana (1J 4, 20), Augustyn dowodził głębokiej wewnętrznej jedności tych dwóch przykazań i twierdził, że ten kto miłuje brata równocześnie widzi Boga, który jest miłością. ${ }^{139}$ Jednocześnie podkreślał, że słowa Chrystusa „...jak Ja was umiłowałem” (J 15, 12) stanowią miarę i model miłości. Doskonała miłość, w porównaniu do tej czysto ludzkiej, nie jest ograniczona jedynie do człowieka i jego doczesnych możliwości, ale jej ostatecznym celem jest doprowadzenie go do Boga, tak by Ten był wszystkim we wszystkich $(1$ Kor 15,28$) .{ }^{140} \mathrm{Bi}-$ skup Hippony utrzymywał ponadto, że wewnętrzna obecność Ducha Świętego jest korzeniem, z którego wyrastają pędy ludzkiej miłości i owoce dobrych czynów. ${ }^{141}$

Szczególną formą realizacji przykazania miłości stanowiło dla Augustyna życie monastyczne, którego ideał odczytywał w wersecie Dz 4, 32. Podkreślał, że jest ono radykalną formą życia chrześcijańskiego, polegającą na zjednoczeniu serc, które realizują miłość zaszczepioną w nich przez Ducha, a będącą jednocześnie obrazem zjednoczenia Trzech Osób Boskich. ${ }^{142}$

Miłość była bowiem dla Augustyna drogą do poznania największego misterium Trójcy Świętej. „Widzisz Trójcę, widząc miłość”. ${ }^{143}$ Rozważania na temat trynitologii to osobny rozdział myśli i duchowości wielkiego biskupa Hippony. Warto jednak na zakończenie podkreślić głęboko personalną i relacyjną koncepcję Trójcy Świętej, która koresponduje z jego rozważaniami na temat serca czystego i miłującego. „Dzięki pojęciu miłości, która w Piśmie Świętym jest

138 Por. Sermo 265, 8.9; Ev. Io. Tr. 17, 8.

139 Por. Ep. Io. Tr. 5, 7.

${ }^{140}$ Por. Ev. Io. Tr. 83, 3.

${ }^{141}$ Por. tamże, 87, 1; En. Ps. 51, 12.

${ }^{142}$ Por. M. F. B e r r o u a r d, La première communauté de Jérusalem comme image de l'unité de la Trinité. Une des exégèses augustiniennes d'Act 4, 32a, Würzburg 1987, s. 207-224.

${ }^{143}$ De Trinitate Libri Quindecim VIII, 8.12: „Vides Trinitatem, si caritatem vides" ; tłumaczenie polskie w: Ś w. A u g u s t y n, O Trójcy Świętej, tłum. M. S t o k ow s k a, Znak, Kraków 1996, s. 281. 
nazwana Bogiem (por. 1J 4, 16), zaczęła się w myśli mej zarysowywać Trójca: miłującego, miłowanego i samej miłości”." ${ }^{144}$ Ta Miłość, Duch Święty, gdy wypełnia serce, rozszerza je. Dlatego proces wzrostu nie kończy się na ziemi, ale będzie trwał w wieczności, gdyż miłość łączy ziemię z niebem, a serce człowieka z Bogiem.

$$
* * *
$$

„Serce” (cor) to jeden z kluczowych, choć wieloznacznych terminów antropologii i duchowości św. Augustyna. Pojawia się wielokrotnie i w różnych kontekstach jako symbol człowieka wewnętrznego (homo interior), ogniskując w sobie wszystkie jego wymiary: cielesny, uczuciowy, wolitywny, intelektualny, duchowy. Nade wszystko jednak termin cor wyraża dynamikę i osobisty aspekt relacji człowieka z Bogiem: „Bóg jest niewidzialny; należy go szukać nie okiem, lecz sercem. (...) musimy oczyścić oko serca, jeżeli chcemy widzieć Boga. Posłuchaj Ewangelii: «Błogosławieni czystego serca, albowiem oni Boga oglądać będą». (...) w duchu widzi wszystko ten, kto miłuje. Przebywaj w miłości, a ona będzie przebywać w tobie; pozostań $\mathrm{w}$ niej, a ona pozostanie w tobie". ${ }^{145}$

Mirosław MEJZNER SAC

${ }^{144}$ De Trinitate Libri Quindecim XV, 3.5: „Per caritatem, quae in Scripturis sanctis Deus dicta est, per quam coepit utcumque etiam Trinitas intellegentibus apparere, sicut sunt amans, et quod amatur, et amor"; tłum. pol. tamże, s. 463.

${ }^{145}$ Ep. Io. Tr. 7, 10: „Deum nemo vidit unquam: res est invisibilis; non oculo, sed corde quaerendus est. (...) volentes videre Deum, oculum quo Deus videri potest, purgemus. Ubi est iste oculus? Audi Evangelium: Beati mundo corde, quoniam ipsi Deum videbunt. (...) intellectu totum simul videt qui habet caritatem. Habita, et inhabitaberis; mane, et manebitur in te"; tłum. pol. W. S z ołd r s k i, W. K a n i a, s. 461-462. 
Słowa kluczowe: Augustyn, serce, obraz Boga, zmysły wewnętrzne, miłość, pokora, modlitwa, Trójca Święta

Keywords: Augustine, heart, God's image, inner senses, charity, humility, prayer, Holy Trinity

\section{„Way of the Heart" in the Experience and Reflection of St. Augustine} Summary

In the writings of St. Augustine, the Latin word cor occurs more than 8,000 times, being one of the most important, though ambiguous, terms of his anthropology and spirituality. As a synonym for the inner man (homo interior) it encompasses the whole life: affective, intellectual, moral and religious. In this sense, it is the privileged place for a personal encounter with God.

Analysis of Augustine's writings reveals a link between the concept of the Trinity and indications concerning the spiritual life of man. Reflections on the "heart" can be put into a kind of triptych: creation "in the image of God", enlightenment by Christ, and expansion by the Holy Spirit. The impact of God on the human heart should find their completion in a voluntarily adopted attitude of adoration, humility and love. 